Tintti Klapuri

\title{
Venäläisen modernistisen runouden suomalainen käännöshistoria, 1918-1930
}

Artikkelini tavoitteena on kartoittaa venäläisen modernistisen runouden rantautumista Suomeen 1920-luvulla tehtyjen käännösten avulla. Näkökulmani on käännöshistoriallinen: vertailen 1920-luvun ruotsinkielistä ja suomenkielistä käännöshistoriaa ja peilaan tilannetta ruotsalaiseen ja eurooppalaiseen käännöshistoriaan. Artikkelin aineisto koostuu Suomessa vuosina 1918-1930 ilmestyneistä käännöksistä, käännösbibliografioista, kirjailijaesittelyistä ja kääntäjien henkilöarkistoista. ${ }^{1}$

Yleisen käsityksen mukaan venäläistä modernismia ei tunnettu Suomessa 1900luvun ensimmäisillä vuosikymmenillä juuri lainkaan. 1920-luvulla käännettiin 1800luvun realistisia klassikoita lähes samaan tahtiin kuin ennen Suomen itsenäistymistäkin, mutta modernistiseksi luokiteltavaa kirjallisuutta vain hyvin vähän (ks. Jänis \& Pesonen 2007, 195-196). Samaan aikaan esimerkiksi ranskalaista symbolistista proosaa ja draamaa oli käännetty jo nidekaupalla ja runouttakin pienen antologiallisen verran. ${ }^{2}$ Muualla Euroopassa venäläinen modernismi sen sijaan kukoisti: Berliinissä ja Pariisissa oli suuret emigranttiyhteisöt, joiden lehdissä ja kustantamoissa esiteltiin uutta venäläistä kirjallisuutta jatkuvasti sekä alkukielellä että käännöksinä (ks. Hübner 2012, 70). Johtavista runoilijoista symbolisti Aleksandr Blokia oli käännetty keskeisille eurooppalaisille kielille vuosikymmenen vaihteessa, ja futuristi Vladimir Majakovskia ja imaginisti Sergei Jeseniniä oli saatavilla englanninkielisissä antologioissa. ${ }^{3}$ Suomeksi Blokia, Majakovskia ja Jeseniniä saatiin ensimmäisen kerran vuonna 1928, kun Olavi Paavolaisen essee "venäläisistä vallankumousrunoilijoista" ilmestyi Aitta-lehdessä ja vuotta myöhemmin kokoelmassa Nykyaikaa etsimässä.

Tilanne oli kuitenkin toisenlainen suomenruotsalaisissa kirjallisuuspiireissä, joiden voidaan aiemman tutkimuksen perusteella arvella olleen huomattavasti paremmin jyvällä uudesta venäläisestä kirjallisuudesta: Edith Södergranin tuotannossa näkyy vaikutteita venäläisestä symbolismista ja futurismista, ja Henry Parland puolestaan tunsi hyvin paitsi avantgarderunoutta myös formalistista kirjallisuusteoriaa. ${ }^{4}$ Luontevat suhteet venäläiseen kirjallisuuteen ja kulttuuriin selittyvät osin sillä, että moni ruotsinkielinen kirjailija, kääntäjä, kuvataiteilija ja muusikko oli kotoisin Pietarista tai monikulttuuriselta Kannakselta. Södergran asui Raivolassa ja kävi koulunsa saksankielisessä St. Petrischulessa Pietarissa. Kuvataiteilija Ina Behrsen (myöh. Colliander) kasvoi ja kouluttautui Pietarissa, Saksassa ja Tsarskoje Selossa. Henry Parland oli syntyisin 
Viipurista ja puhui ensimmäisinä kielinään saksaa ja venäjää. Myös säveltäjä Ernst Pingoud, joka kirjoitti sekä modernistilehti Ultraan että Tulenkantajat-albumiin, oli äitinsä puolelta Viipurin Sesemanneja ja suoritti musiikkiopintonsa Pietarissa. Keskeisistä suomenkielisistä 1920-30-lukujen modernisteista venäjää osasi hiukan vain Kannaksella kasvanut Paavolainen. Myös yhteydet Helsingissä sotienvälisenä aikana kukoistaneeseen venäläiseen emigranttikulttuuriin olivat ruotsinkielisellä puolella tiiviimmät. ${ }^{5}$ 1920-luvun alun Helsingissä toimi hetken aikaa jopa suomenruotsalainen pienkustantamo Biblion, joka julkaisi yhteistyössä emigranttien kanssa venäjänkielistä kirjallisuutta, erityisesti Leonid Andrejevia, ja käännätti suomalaista ja ruotsalaista kirjallisuutta venäjäksi (ks. Hellman 2009).

\section{Käännöshistoriasta metodologiana}

Käännöshistoriallisella tutkimuksella tarkoitetaan käännösten tarkastelua niiden kulttuuri-, kirjallisuus- ja henkilöhistoriallisessa kontekstissa. Artikkelini lähtökohtana ovat Anthony Pymin tutkimuksessaan Method in Translation History (1998) esittämät näkemykset käännöshistoriallisesta tutkimuksesta arkeologisena analyysina. Pym (1998, $\mathrm{x}$-xi) korostaa kääntäjien merkitystä yhteiskunnallisina ja kulttuurisina toimijoina ja esittää käännöshistoriallisen tutkimuksen keskeisiksi tavoitteiksi selvittää, miksi käännökset on tehty ja mikä on kääntäjän rooli näiden käännösten tuottamisessa. Käännöshistoriallinen tutkimus on siten lähtökohdiltaan kontekstuaalista: käännösten kielelliset piirteet ovat usein sivuroolissa, kun painotetaan kääntämiseen liittyviä yhteiskunnallisia ja kulttuurisia tekijöitä sekä kääntäjän mahdollisesti merkittävääkin roolia kirjallisuuden välittäjänä. Kuitenkin myös kielellisten seikkojen tarkastelu on osa käännöshistoriaa: kääntäjän työssään tekemien valintojen kuten vierassanojen tai käännöslainojen käyttäminen kertoo osaltaan käännöksen ajankohtana vallinneista käännösnormeista (ks. esim. Leppihalme 2007, 365; Pym 1998, 106-107). Pym (mt., 6-7) esittää käännöshistoriallisen tutkimuksen osa-alueina yhtäältä "käännösarkeologian" eli käännöksen tekijän, julkaisijan, ajankohdan ja käännöksen vaikutuksen selvittämisen ja toisaalta tehtyjen arkeologisten löytöjen selittämisen: mitkä syyt ovat vaikuttaneet siihen, että tietyt tekstit ja tekijät on valittu käännettäviksi tiettynä ajankohtana. Pientä kielialuetta ja melko lyhyttä ajanjaksoa tarkasteltaessa on otettava huomioon myös se seikka, että kääntäjiä on varsin vähän, minkä vuoksi on syytä olettaa yksittäisillä toimijoilla olevan suuri merkitys käännettävien tekstien valinnassa (ks. myös Hekkanen 2010, 40).

Nils Håkanson hahmottelee osin Pymin näkemyksiin pohjaavassa tutkimuksessaan Fönstret mot öster: Rysk skönlitteratur i svensk översättning 1797-2010 med en fallstudie av Nikolai Gogols svenska mottagande (2012) neljä keskeistä käännöstoimintaa kontekstuaalisessa mielessä ohjaavaa tekijää, jotka painottuvat historiallisesta tilanteesta ja käännöksen luonteesta riippuen eri tavoin. Håkansonin $(2012,46)$ mukaan käännet- 
tävän kirjallisuuden valintaan vaikuttavat ensinnäkin kognitiiviset motiivit, joilla tarkoitetaan käännöksen motivointia informaation tuottamisella lähtömaan kulttuurista; tällöin kyse on usein yhteiskunnallisesti tai poliittisesti ajankohtaisesta kirjallisuudesta. Ruotsissa venäläisestä kirjallisuudesta tehdyissä käännöksissä kognitiiviset syyt ovat usein olleet etualalla, koska Venäjä on koettu vihollismaaksi. Kääntämisellä voi olla myös universaali motivaatio, jolloin lähtötekstin taiteelliset arvot nähdään kääntämisen arvoisiksi lähtömaan kulttuurista tai poliittisesta tilanteesta riippumatta (mt., 47). Ruotsissa sotienvälisenä aikana julkaistu venäläinen kirjallisuus on lähtökohdiltaan yllättävän useinkin epäpoliittista - tai ainakin käännettävien tekstien valinta pyritään perustelemaan käännösten esipuheissa esteettisin syin (mt., 102). Lisäksi kääntämiseen vaikuttavat kohdemaan kirjallisuuskentän sisäiset motiivit, kuten se onko teksteillä jokin erityissuhde kohdemaahan, sekä kansainväliset käännöstendenssit eli se mitä muille kielille käännetään (mt., 47).

Artikkelissani sovellan Håkansonin kontekstuaalista lähestymistapaa korostavia näkemyksiä, mutta kiinnitän huomiota myös joihinkin kääntäjien käyttämiin kielellisen tason strategioihin, joiden tarkastelun arvelen elävöittävän analyysiä. Samoin huomioin mahdollisuuksien mukaan paratekstien roolin käännösten selittäjinä: antologioiden esipuheet tai kirjailijaesittelyt selventävät usein hyvin kääntäjän tai kustantajan näkemyksiä käännösten merkityksestä ja niiden kääntämisen taustalla vaikuttaneista syistä.

\section{Rafael Lindqvist ja käännösantologia Sånger i rött och svart}

Kun otetaan huomioon, että nimenomaan suomenruotsalaisilla modernisteilla oli usein siteitä Kannakselle ja Pietariin, tuntuu yllättävältä, että suurin osa venäläisen modernismin sotienvälisen ajan ruotsinnoksista syntyi täysin modernististen piirien ulkopuolella. Koko vuosisadan alkupuolen ehdottomasti merkittävin ruotsintaja sekä käännösten määrän että niiden varhaisuuden suhteen on oululaissyntyinen suomenruotsalaisen kulttuurikentän monitoimimies Rafael Lindqvist (1867-1952). Lindqvistin ruotsinnokset myös levisivät laajalle, sillä hänen vuosisadan alusta lähtien tekemiään käännöksiä ilmestyi vielä toisen maailmansodan jälkeenkin Ruotsissa julkaistuissa antologioissa, esimerkiksi kokoelmassa En bukett rysk lyrik (1953). Lindqvist aloitti työn venäläisen modernismin parissa vuonna 1904 kääntämällä 12 runon verran symbolisti Konstantin Balmontia kokoelmaansa Ur Rysslands sång I. ${ }^{6}$ Hän ruotsinsi myös toista keskeistä symbolistia Valeri Brjusovia Fyren-lehteensä jo vuonna 1909. Suomeksi Brjusovia käännettiin vasta vuonna 1930 Nuoreen Voimaan ja vuonna 1946 kokoelmaan Venäjän runotar, siitä huolimatta, että runoilija vieraili ahkerasti Imatran seudun täysihoitoloissa kesiään viettämässä ja kirjoitti lukuisia runoja suomalaisesta luonnosta ja suomen kielestä innoittuneena. Varhaisissa Brjusov-käännöksissä näkyvät hyvin Håkansonin (2012, 47) esille nostamat kohdemaan sisäiset käännösmotiivit: Lindqvist valitsi ensimmäisenä 
käännettäväksi nimenomaan runoilijan Suomea käsittelevän runon "Till Finlands folk" ("K finskomu narodu"). Vastaavalla tavalla Brjusovia Ruotsissa kääntänyt Alfred Jensen valikoi antologiaansa Rysk litteratur (1912) juuri runoilijan Ruotsi-aiheiset runot "Till Sverige" ("K Švetsii") ja "På Mälaren" ("Na Melare").

Merkittävin Lindqvistin käännöksistä on kokoelma Sånger i rött och svart (1924), joka on Pohjoismaissa ainutlaatuisen varhainen ja koko Euroopankin kontekstissa joiltakin osiltaan harvinainen käännösantologia. Kokoelmaan sisältyy esimerkiksi Blokin runoelma "De tolv" ("Dvenadtsat", 1918), Jeseninin "Tavaristsj" ("Tovarištš", 1917) sekä lukuisia Majakovskin runoja. Ruotsissa Blokia, Jeseniniä ja Majakovskia käännettiin vasta sotien jälkeen, ja suomeksi kultakin ilmestyi yksi runo Paavolaisen Nykyaikaa etsimässä -kokoelmassa vuonna 1929. Lindqvist ruotsinsi kokoelmaan myös avantgarderunoilijoita, joita käännettiin suomeksi joko vasta vuosikymmeniä myöhemmin tai joita ei edelleenkään ole käännetty: mukana ovat talonpoikaisrunoilija Nikolai Kljujev, egofuturisti-imaginisti Rurik Ivnev ja imaginisti Anatoli Mariengof. Kahta ensimmäistä ei ole koskaan suomennettu, ja Mariengof löydettiin vasta 1900-luvun lopulla (ks. Hellman 2008, 202). Ivnev-käännös on harvinainen koko Euroopan kontekstissa, sillä hänen tekstejään ei ole juuri käännetty muille kielille. Lisäksi Lindqvist valitsi antologiaan Andrei Belyin lyriikkaa; suomeksi Belyiltä on edelleen saatavilla ainoastaan 1960-luvulla käännetty romaani Peterburg (1922), mistä syystä hänet Suomessa usein hahmotetaankin yksinomaan romaanikirjailijaksi.

Lindqvistin Suomen oloissa poikkeuksellinen uuden venäläisen kirjallisuuden tuntemus selittyy hänen suhteillaan Helsingin yliopiston kirjaston slaavilaiseen osastoon, jonka amanuenssina hän toimi vuosina 1902-1906. Slaavilainen osasto oli autonomian aikana vapaakappalekirjasto, johon toimitettiin suuri osa sekä Venäjällä että ulkomailla ilmestyneestä kirjallisuudesta. Esimerkiksi merkittävä osa 1910-luvun futuristisista pienpainatteista oli kielitaitoisten lukijoiden ulottuvilla, mutta harva kirjaston ulkopuolinen kirjallisuudenharrastaja tiesi vapaakappaleiden olemassaolosta. Sånger $i$ rött och svart -antologian kohdalla Lindqvistin keskeisenä lähteenä on ollut slaavilaisessa kirjastossa saatavilla ollut, Mysl-emigranttikustantamon Berliinissä vuonna 1921 julkaisema antologia Poezija bolševistskih dnei ("Bolševististen päivien runoutta"), johon ruotsinnoskokoelman alaotsikko Ett urval ryska dikter frän bolsjevismens dagar suoraan viittaa. Lindqvistin kokoelmaan valitsemat runoilijat ovat pääpiirteissään samat kuin berliiniläisessä antologiassa; keskeisin ero on Majakovskin lyriikan laaja esittely, joka lähdeteoksesta puuttuu kokonaan. Myös runovalinnoissa on jonkin verran variaatiota.

Sånger i rött och svart -antologian motivaatio on monitahoinen. Yhtäältä pyrkimyksenä on ajankohtaisen tiedon tuottaminen vihollismaaksi koetusta Neuvosto-Venäjästä. Toisaalta suurin osa antologiaan käännetystä lyriikasta on historiallisen ajankohdan yläpuolelle nousevaa ja sittemmin kanonisoitua modernistista lyriikkaa, ja niinpä antolo- 
gian taustalla voi nähdä pääosin universaalin motivaation. Pyrkimys nähdä uusi venäläinen lyriikka vallankumouksesta riippumattomana näkyy myös Hjalmar Dahlin (1924, vii-viii) kokoelmaan kirjoittamassa esipuheessa, jossa kritisoidaan näkemyksiä Blokin "Kahdestatoista" pelkkänä vallankumousrunoelmana ja pyritään lähestymään tekstiä runoilijan muun tuotannon kontekstissa. Dahlin esipuhe on tässä mielessä samassa linjassa Ruotsissa sotienvälisenä aikana ilmestyneiden uuden venäläisen kirjallisuuden käännösten esipuheiden kanssa: kuten Håkanson $(2012,102)$ toteaa, esimerkiksi Aleksei Tolstoin romaanin Aelita (1923) ruotsinnoksen Resan till Mars (1924) esipuheessa lukijaa ohjataan selvästi epäpoliittiseen luentaan. Universaalin näkemyksen voi nähdä ohjailleen Lindqvistin toimintaa yleisemminkin: äärikonservatiivisista mielipiteistään huolimatta hän pyrki esittelemään venäläistä kulttuuria ja kirjallisuutta yli poliittisten rajojen, mikä näkyy esimerkiksi hänen vuosisadan alussa kirjoittamissaan ihailevissa kirjoituksissaan Maksim Gorkista (SLSA 842). ${ }^{7}$ Lindqvist itse perustelee käännöstoimintaansa suurimman käännöstyönsä, vuonna 1936 valmistuneen Ur Rysslands sång -sarjan viimeisen osan esipuheessa nimenomaan kognitiivisia ja universaaleja päämääriä yhdistellen. Hän selostaa pyrkineensä tässä bylinoista nykyrunouteen etenevässä massiivisessa käännössarjassa luomaan ”poeettis-historiallisen panoraaman venäläisen kansan elämästä”, jolloin valintaprosessia ovat ohjanneet sekä esteettiset että poliittiset motiivit: "Plikten att göra detta panorama så fullständigt som möjligt har föranlett författaren [Lindqvist] att vid sidan av rent poetiska dikter medtaga en del diktalster av större historiskt än poetisk intresse" (Lindqvist 1936).

Alkutekstin luonteeseen katsomatta Lindqvistin ruotsinnoksille on ominaista runsas venäjänkielisen sanaston käyttö. Venäjänkielinen termistö leimaa esimerkiksi Blokin "Kahdentoista" käännöstä kauttaaltaan, ja Lindqvist myös selittää käyttämiään termejä alaviittein:

Blåsten stämde upp en fuga,

oj vjuga, $\left.{ }^{*}\right)$, oj vjuga!

Ej hörs stämma, ej ses stuga

ens på fyra alnars håll.

Trattlikt snön i höjden steg,

för ett skydrag likt i väg...

Åh, en sån purgá, ${ }^{* *}$ ) o Jesus!

Pietka! Stolle, käften håll!

*) Snöstorm i Ryssland.

**) Snöstorm på tundran.

$(\text { Blok 1924, 32. })^{8}$

Alkukielisen termistön käytöllä pyritään käännöksissä usein eksoottisuuden vaikutelmaan (ks. esim. Leppihalme 2007, 368), mikä näkyy hyvin Lindqvistin Blok-kään- 
nöksessäkin. Toisaalta erityisesti alaviitteiden käytön voi nähdä korostavan käännöksen kognitiivista ulottuvuutta: venäjänkielisten termien käyttö ja niiden avaaminen avaa samalla lukijalle myös venäläistä kulttuuria.

Modernistisissa piireissä Sånger i rött och svart -antologian käännösten taso herätti välitöntä kritiikkiä. ${ }^{9}$ Hagar Olsson (1924) kritisoi Lindqvistin ruotsinnoksia vanhahtavuudesta ja juuri venäjänkielisen termistön viljelemisestä. ${ }^{10}$ Konservatiivisista mielipiteistään ja juutalaisvihamielisyydestään tunnetun Lindqvistin ja suomenruotsalaisten modernistien välit olivat ylipäätään viileät. Lindqvist näki esimerkiksi Quosegon piirin toiminnan elitistisenä puuhasteluna (ks. Blinkfyren 1928). Quosegossa puolestaan napautettiin svekomaani Lindqvistiä pilapiirroksessa, jossa yläluokkaisten suomenruotsalaisten arvojen puolesta taisteleva runoilija Bertel Gripenberg esitetään Don Quijotena ja Lindqvist tämän Sancho Panzana (Quosego 1928). Venäläisen modernistisen ja avantgarderunouden välittäjänä Lindqvist nousee kuitenkin kirkkaasti modernistien yläpuolelle mitä tulee käännösten määrään ja levinneisyyteen.

\section{Modernistien avantgardekäännökset}

Vaikka modernistien käännökset ovatkin vähäisiä, erityisesti varhaisimmat ruotsinnokset ovat varsin kiinnostavia. 1920-luvun taitteen Euroopassa Blok, Majakovski ja Jesenin olivat jo selvästi vakiinnuttaneet paikkansa uuden venäläisen runouden airuina, ja tätä kolmikkoa myös käännettiin ensimmäisenä eri kielille. Suomessa sen sijaan käännettiin ensimmäisenä niin venäläisessä kuin läntisessä kirjallisuudentutkimuksessa vähälle huomiolle jäänyttä egofuturisti Igor Severjaninia. ${ }^{11}$ Severjaninin parissa puuhaili vuonna 1922 kaksikin ruotsintajaa: Jarl Hemmerin ruotsinnokset ilmestyivät käännösantologiassa Lyriska översättningar ja Edith Södergranin käännökset Ultrassa. Hemmerin käännösantologia sisältää sekä saksalaista että venäläistä runoutta. Pääpaino on vanhemmassa, pääosin romanttisessa lyriikassa, uudemmasta venäläisestä kirjallisuudesta mukaan ovat mahtuneet Severjaninin lisäksi symbolistit Balmont ja Brjusov sekä dekadenttirunoilija Semjon Nadson. Valinnat kertovat Hemmerin kiinnostuksesta romanttiseen ja symbolistiseen runouteen ylipäänsä; myös Severjanin-käännös "Morgon" ("Russkaja", 1913) edustaa runoilijan aistillista luontorunoutta ja muodostaa luonnollisen jatkumon symbolistirunoilijoista ja Hemmerin omasta suosikista Nadsonista uusimpaan lyriikkaan. ${ }^{12}$

Södergranin Severjanin-käännökset ovat erityisen merkittäviä siksi, että kaksikielinen Ultra tavoitti myös suomenkielisen lukijakunnan. Nuoren Olavi Paavolaisen tiedetäänkin ihastuneen Södergranin käännöksiin, erityisesti urbaania koneromantiikkaa uhkuvaan "Ouvertureen" ("Uvertjura", 1915) eli "Ananaksiin samppanjassa":

Ananas i Champagne! Ananas i Champagne!

Hur underbart gnistrande, gott och pikant! 
Jag är halvt uti Norge, jag är halvt uti Spanien, impulsivt inspirerad, jag fattar mitt stift.

Surr av aeroplan! gny av automobiler! expressernas vindtjut! isjakternas flykt. Någon kysses med våld, någon illa blir slaget! Ananas i Champagne - är kvällarnas puls.

Bland damer nervösa och spirituella till en drömfars förvandlar jag livstragedien... Ananas i Champagne! Ananas i Champagne! Från Moskva till Tokio, från New York upp till Mars!

$(\text { Severjanin 1922a. })^{13}$

Södergranin käännös luopuu Severjaninin tiukasta mitallisuudesta mutta on sisällöllisesti alkutekstille uskollinen; ainoastaan alkutekstin "Nagasaki” on kotoutettu tutummaksi "Tokioksi". Uuno Kailaan "Ouverturesta" Tulenkantajat-lehteen vuonna 1930 tekemä suomennos puolestaan pohjautunee Södergranin ruotsinnokseen, jonka kanssa se on lähes identtinen (ks. Severjanin 1930).

Södergranin innostus Severjaniniin liittyy yhtäältä tämän varhaisrunouden tematiikkaan, jossa individualistinen kokemus ja luontosymboliikka yhdistyvät varsin samaan tapaan kuin Södergranilla itsellään. Olssonin ja Södergranin kirjeenvaihdosta käy ilmi, että Södergranille juuri Severjanin oli kaikkein moderneimman runouden edustaja, hänen oma vastineensa Venäjällä - siitä huolimatta että tämä oli toistaiseksi "korviaan myöten buduaareissa": "Minä haluaisin vangita erinäisiä sieluja. [--] Igor Severjanin on nyk. Venäjän suurin lyyrikko. [--] Hän on hyvin suuri voima ja olletikin valmis meidän aatteillemme. [--] Hänestä tulee silta Venäjään, hänessä me saamme kyllä jalkeille Venäjän hienoimmillaan.” (Olsson 1990, 30; kursiivi alkuperäinen.) ${ }^{14}$ Toisaalta Södergranin intohimoinen asenne selittynee sillä, että Severjaninin runous - ja hänen tietoisen oscarwildemainen dandyhahmonsa - vetosi nimenomaan nuoriin naisiin, mukaan lukien Södergranin luokkatoverit Petrischulessa, jotka jäljensivät Severjaninin runoja Södergranin muistikirjaan (SLSA 566). Samalla se, että Södergran näkee juuri Severjaninin venäläisen uuden runouden poikkeusyksilönä, kertoo myös runoilijan kasvavasta etäisyydestä neuvostovenäläiseen kulttuuriin, jossa Severjanin on 1920-luvun alussa jo auttamattomasti menneisyyden hahmo.

Ruotsinkielisellä puolella merkittävin osa uuden venäläisen kirjallisuuden käännöksiä ilmestyi siten modernististen piirien ulkopuolella; Hemmerin ja Södergranin Severjanin-käännösten lisäksi ainoa modernistien tekemäksi laskettava venäläisen avantgarden käännös on Ina Behrsenin vuonna 1928 Quosegossa ilmestynyt Jeseninruotsinnos "Förvandling" ("Preobraženije", 1917). Suomenkielisissä piireissä sen sijaan venäläinen avantgarde kiinnosti tehtyjen käännösten perusteella lähinnä Tulenkantajia, joiden suhteet venäläisen kirjallisuuden kenttään olivat kuitenkin pääasiassa epäsuorat. 
Tulenkantajista parhaiten venäläistä kirjallisuutta tunsi Kannaksen Kivennavalta kotoisin ollut Paavolainen, joka osasi venäläisten lastenhoitajiensa ansiosta vähän myös venäjää (Riikonen 2014, 31). Paavolainen esitteli uutta venäläistä kirjallisuutta suomalaiselle yleisölle jo vuonna 1927, jolloin viimeisessä Tulenkantajat-albumissa ilmestyi käännös Ilja Ehrenburgin tuoreesta "Uusi romantiikka” -esseestä sekä Paavolaisen esseeseen kirjoittama pitkä esipuhe. Venäläisen avantgarden välittymisen kannalta vaikuttavampi on kuitenkin jo ilmestymisaikanaan suurta huomiota saaneessa $N y k y$ aikaa etsimässä -teoksessa (1929) ilmestynyt essee "Venäläisiä vallankumousrunoilijoita: Block - Majakovski - Jessenin”, jossa Paavolainen taustoitti 1910-20-lukujen modernistista ja avantgardistista kirjallisuutta ja tarjosi kultakin sen keskeisimmältä edustajalta yhden kokonaisen tai osittaisen runokäännöksen.

Paavolainen esittelee venäläisen avantgarderunouden suhteessa italialaiseen futurismiin ja näkee sen vain pinnallisesti vallankumoukseen yhdistyvänä; tässä mielessä ensimmäinen suomenkielinen esitys venäläisestä modernismista on samassa linjassa suomenruotsalaisten esittelyjen kanssa. Blok-tulkintoihinsa Paavolainen on todennäköisesti saanut vaikutteita Hagar Olssonin esseessään "Ett revolutionsmysterium” (1925) esittämistä näkemyksistä. Taustalla näkyy myös hänen samoin hyvin tuntemansa saksalainen kirjallisuuskeskustelu; kuten H. K. Riikonen (2016, 17-18) toteaa, Nykyaikaa etsimässä -kokoelman esitykset avantgarderunoudesta pohjautuvat pitkälti aiempiin lehtiartikkeleihin ja yleisesityksiin. Saksalainen vaikutus näkyy myös käännöksissä. Blokin "Skyyttien" ("Skify", 1918) käännös on Yrjö Jylhän käsialaa, Majakovskin "150 miljoonaa" ("150 000 000", 1921) Paavolainen mainitsee kääntäneensä itse, mutta sekä Majakovski-käännös että Jeseninin runoelman "Sorokoust" (1920) osittainen käännös on mitä todennäköisimmin tehty ainakin saksannosten avustuksella, mistä kertovat myös Paavolaisen käyttämät runoilijoiden nimien kirjoitusasut (Jänis \& Pesonen 2007, 197).

Paavolaisen esseen varjoon ovat jääneet muut Tulenkantajien piirissä tehdyt käännökset, joista osa on melko harvinaisia, joskaan ei kovin varhaisia. Runoilija Katri Suorannan vuonna 1929 ilmestynyt käännös "Yksinäisyys" Nikolai Gumiljovin runosta "Odinotšestvo" (1909) on ainoita runoilijalta suomennettuja tekstejä. ${ }^{15}$ Suorannan Ahmatova-käännös "Harmaasilmäinen kuningas" ("Seroglasyi korol”, 1912) puolestaan ilmestyi Nuoressa Voimassa vuonna 1932. Molemmat käännökset ovat varhaisempia kuin Rafael Lindqvistin muutamaa vuotta myöhemmin julkaisemat ensimmäiset akmeistien ruotsinnokset. Suoranta käänsi 1930-luvun taitteessa Nuoreen Voimaan myös Balmontia (1928) ja Brjusovia (1930).

1930-luvulla tehdyt käännökset jäävät tämän artikkelin aikarajauksen ulkopuolelle, mutta alustavasti voidaan todeta, että poliittisen ilmapiirin voimakas jakautuminen näyttää vaikuttaneen myös tehtävien käännösten laatuun ja määrään. Muutos näkyy erityisen selvästi suomenkielisellä puolella, jolla yhteyksiä venäläisiin kirjailijoihin alkoi 
olla aiempaa enemmän. Käännöksiä ilmestyi varsinkin vasemmistolaistuneessa Tulenkantajat-lehdessä: 1920-luvun kokeellisen prosaistin Boris Pilnjakin Suomen-vierailun jälkeen vuonna 1934 julkaistiin Pilnjakin novelli "Belokonskin maatila” ja seuraavana vuonna kovan linjan kommunistin Ami Aarron (oik. Armas Äikiä) Jesenin-käännös "Uusi Venäjä" ("Rus Sovetskaja”, 1924). Vasemmistolaisissa lehdissä ilmestyi runsaasti myös täysin poliittista kirjallisuutta; tässä kehityslinja on hyvin samansuuntainen kuin Ruotsissa (ks. Håkanson 2012, 46-47). Modernistista kirjallisuutta ilmestyi myös suomennosantologioissa, kuten Yrjö Jylhän Runon purressa (1934), johon modernistisesta lyriikasta pääsi mukaan tosin vain Blokin "Kaksitoista”. Pari vuotta myöhemmin ilmestyi pienin muutoksin myös Jylhän alun perin Paavolaisen esseeseen suomentama "Skyytit" antologiassa Maailmankirjallisuuksien kultainen kirja: Slaavilaiset kirjallisuudet (1936). Ruotsinkielisellä puolella taas Lindqvist käänsi antologiaansa Rysslands judiska skalder (1935) muun muassa Boris Pasternakia ja Osip Mandelštamia. Erityisesti Mandelštam-käännös "Frihetens skymning" ("Sumerki svobody", 1918) on tärkeä, sillä seuraavan kerran runoilijaa käännettiin ruotsiksi vasta vuonna 1972 (ks. Åkerström 2010, 354). Vuonna 1936 ilmestyi myös Lindqvistin venäläisen runouden sarjan Ur Rysslands sång I-II jälkimmäinen osa, jossa julkaistiin aiemmin kokonaan ruotsintamatonta modernistista lyriikkaa, kuten Ahmatovaa ja Gumiljovia.

\section{Lopuksi}

Olen artikkelissani tarkastellut venäläisen modernistisen runouden rantautumista Suomeen 1920-luvulla vertailemalla suomennosten ja ruotsinnosten käännöshistoriaa suhteessa toisiinsa ja eurooppalaisen käännöshistorian pääpiirteisiin. Käännöksiä teki suppeahko joukko kääntäjiä: ruotsiksi käänsivät Rafael Lindqvist, Edith Södergran, Jarl Hemmer ja Ina Behrsen, suomeksi (välikielen kautta) Olavi Paavolainen, Yrjö Jylhä, Katri Suoranta ja Uuno Kailas. Käännökset ilmestyivät joko erillisinä antologioina (Sånger $i$ rött och svart), osana antologioita (Lyriska översättningar), lehdissä (Veckans krönika, Fyren, Ultra, Quosego, Tulenkantajat, Nuori Voima, Aitta) tai esseekokoelmissa (Nykyaikaa etsimässä).

Käännöshistoriallinen analyysi paljastaa ensiksikin merkittävän eron ruotsinkielisen ja suomenkielisen kontekstin välillä. Ruotsinnoksia tehtiin huomattavasti enemmän, ja ne olivat varhaisempia. Suomenkielisellä puolella sallittiin välikielen käyttö, mikä kertoo venäjäntaitajien vähäisestä määrästä. Ruotsinnokset taas tehtiin järkiään suoraan alkukielestä. Eroja tietämyksessä uudesta venäläisestä kirjallisuudesta ei kuitenkaan pidä liioitella: on todennäköistä, että venäläistä modernismia tunnettiin suomenkielisellä puolella paremmin kuin käännöshistoria antaa ymmärtää, sillä tuntumaa saatiin varhaisten ruotsinnosten ja saksannosten kautta.

Toinen keskeinen havainto on se, että osa 1920-luvulla tehdyistä ruotsinnoksista on varhaisia myös verrattuna Ruotsissa tehtyihin käännöksiin ja eräiltä osin myös muualla 
Euroopassa tehtyihin käännöksiin. Kääntäjä Rafael Lindqvistin merkitys venäläisen modernismin ja avantgarden välittäjänä on erityinen. Siitä huolimatta että Lindqvist suhtautui modernistien pyrintöihin ynseästi, hän toi usein ensimmäisenä ruotsinkielisten lukijoiden ulottuville ajan moderneinta ja radikaaleinta venäläistä runoutta. Lindqvistin käännöstyön motivaatio onkin erityisen kiinnostava. Sånger i rött och svart -antologia on luonteeltaan kansainvälinen kokoelma, jonka käännösvalinnoissa ei näy kohdemaan sisäisiä erityispiirteitä. Vaikka Lindqvistiä epäilemättä on motivoinut myös pyrkimys tuottaa tietoa muuttuvasta Venäjästä, antologia näyttäytyy päämääriltään universaalina. Aikansa paras venäläinen runous löysi pohjoismaisen lukijansa pääosin Lindqvistin kautta aina 1920-luvulta 1950-luvulle asti, sillä saamastaan kritiikistä huolimatta hänen käännöksiään julkaistiin uudestaan ruotsalaisissa antologioissa vielä toisen maailmansodan jälkeenkin.

Kolmanneksi 1920-luvun käännöshistorian analyysi osoittaa, että venäläinen avantgarderunous saapui Suomeen hieman toisessa järjestyksessä kuin Euroopassa yleensä. Tässä näkyy yksittäisten kääntäjien ja erityisesti Edith Söderganin suuri merkitys. Södergranin henkilökohtaisen Severjanin-innostuksen vuoksi nykyperspektiivistä melko perifeerinen runoilija päätyi ruotsinkielisten - ja jossain määrin suomenkielistenkin - lukijoiden käsiin aiemmin kuin Blok, Majakovski ja Jesenin, joita käännettiin muualla Euroopassa samaan aikaan. Södergranin ja Severjaninin suhde on kiinnostava ja ansaitsisi tarkemman tutkimuksen. Sama koskee 1930-luvun käännöshistoriaa, johon läheisempien kirjallisten kontaktien ja vasemmistolaistuvan kulttuurilehdistön kehittyminen näyttäisi vaikuttavan voimakkaasti.

\section{Viitteet}

${ }^{1}$ Käännösbibliografiat poikkeavat toisistaan merkittävästi sen suhteen, esitetän̈kö niissä vain erikseen painetut teokset vai myös lehdissä ilmestyneet käännökset, joiden osuus on erityisesti lyriikan kohdalla suuri. Ben Hellmanin Venäläisen kaunokirjallisuuden suomennosten bibliografia 1876-2007 (2008) sisältää ainoastaan kokonaisteokset ja antologiat, kun taas Hans Åkerströmin Bibliografi över rysk skönlitteratur översatt till svenska (2005) kattaa myös suurimman osan lehdissä ilmestyneistä käännöksistä. Sama koskee kolmatta artikkelini kannalta keskeistä käännösluetteloa, Friedrich Hübnerin kommentoivaa bibliografiaa Russische Literatur des 20. Jahrbunderts in deutschsprachigen Übersetzungen (2012). Englanniksi ja ranskaksi käännetystä venäläisestä kirjallisuudesta ei ole yhtä kattavia hakuteoksia, ainoastaan eri aikakausia tai kirjailijoita käsitteleviä bibliografioita.

${ }^{2}$ L. Onerva käänsi pienen, myös Baudelairea ja Verlainea sisältävän antologiallisen vuonna 1912; seuraava laajempi suomennoskokoelma, Ranskan kirjallisunden kultainen kirja, ilmestyi kuitenkin vasta vuonna 1934 (Suomela-Härmä 2007, 113). Proosan puolella ranskalaisia symbolisteja käännettiin huomattavasti venäläisiä enemmän, esimerkiksi Maeterlinckia useamman niteen verran (sekä proosaa että näytelmiä) aivan 1900-luvun alusta alkaen. ${ }^{3}$ Aleksandr Blok (1880-1921), "nuoremman" polven eli ranskalaisesta symbolismista irtautuvan venäläisen symbolismin johtohahmo yhdessä Andrei Belyin kanssa. Blokin 
varhaistuotannossa näkyy erityisesti Vladimir Solovjovilta ammentava ikuisen naisellisuuden idea, kun taas hänen myöhemmässä tuotannossaan korostuu naishahmoinen Venäjä. Vladimir Majakovski (1893-1930), venäläisen futurismin ja vallankumouskirjallisuuden tunnetuin kauhukakara. Sergei Jesenin (1895-1925), Venäjän maaseudun runoilija ja keskeinen imaginisti. Jeseninin tuotannossa kilpistyvät modernisoituvan Venäjän ristiriidat. Blokin runoelmat "Skyytit" ("Skify", 1918) ja "Kaksitoista" ("Dvenadtsat", 1918) käännettiin englanniksi antologiaan Modern Russian Poetry ja saksaksi kahdessa eri niteessä vuonna 1921 (ks. Blok 1921a ja 1921b). Jeseniniä käännettiin samoin englanniksi Modern Russian Poetry -kokoelmaan ja Majakovskia Literary Review'hun vuonna 1922.

${ }^{4}$ Aiemmin aiheesta tehty tutkimus koskee nimenomaan Södergranin ja Parlandin tuotannon suhdetta venäläiseen kirjallisuuteen. Venäläisen modernismin ja Södergranin runouden välistä suhdetta ovat analysoineet esimerkiksi Martin Nag (2006) ja Ebba Witt-Brattström (1997). Ks. myös Bodin 1987 ja Broemer 2009. Hanna Ruutu (2011) ja Per Stam (1998) puolestaan ovat käsitelleet venäläisen avantgarden ja formalistisen kirjallisuusteorian näkymistä Henry Parlandin teksteissä. Ks. myös Zilliacus 2014.

${ }^{5}$ Helsingissä toimi 1920-luvulla aktiivinen emigranttiyhteisö, joka julkaisi venäjänkielisiä lehtiä, järjesti kulttuuritilaisuuksia ja kutsui Suomeen venäläisiä kirjailijoita, taiteilijoita ja teatteriväkeä (Pachmuss 1988, 40-46; Baschmakoff \& Leinonen 2001). Suomessa ilmestyneissä emigranttilehdissä Russkije vesti, Novyje russkije vesti ja Novaja russkaja žizn julkaistiin myös modernistista runoutta kuten akmeisti Anna Ahmatovaa, egofuturisti Igor Severjaninia ja symbolisti Konstantin Balmontia.

${ }^{6}$ Konstantin Balmont (1867-1942), "vanhemman" polven venäläisen symbolismin eli ranskalaisesta symbolismista vaikutteita saaneen dekadentin modernismin tunnetuin edustaja yhdessä Valeri Brjusovin (1873-1924) kanssa. Balmontia käänsivät myös Adèlaide Grönlund perhelehteen Veckans krönika ja Jarl Hemmer antologiaan Lyriska översättningar, mutta näitä vuosina 1916 ja 1922 ilmestyneitä käännöksiä ei enää voi pitää erityisen varhaisina. Grönlundin kääntämä teksti on tosin luonteeltaan melko harvinainen: kyse on Balmontin Japani-aiheisesta matkakertomuksesta "Sagolandet (Tvenne veckor i Japan)". Grönlund (1864-1921) oli pietarilaissyntyinen valtioneuvos Carl Erik Grönlundin tytär, joka muutti Suomeen todennäköisesti vuosisadan vaihteessa. Hänen nuorempi veljensä Julius toimi senaatissa kielenkääntäjänä vuosisadan alusta aina Suomen itsenäistymiseen saakka (Ylioppilasmatrikkeli 1853-1899), ja Adèlaide Grönlund sai käännöstehtäviä mahdollisesti veljensä kontaktien kautta. Hän käänsi myös emigranttikirjailija Nadežda Teffin kirjeitä, jotka ilmestyivät Veckans krönikassa vuonna 1918. Suomeksi Balmontia on käännetty erittäin vähän ja myöhään, ensimmäisen kerran vasta 1930-luvun vaihteessa, jolloin Katri Suoranta käänsi muutaman runon Nuoreen Voimaan. Ruotsissa Balmontia sen sijaan julkaistiin jo 1900-luvun alussa, joskaan ei yhtä laajasti kuin Suomessa (ks. Åkerström 2005, 37-39).

${ }^{7}$ Paradoksaalisen myönteinen asenne Gorkia kohtaan koski myös Lindqvistin ystävää, pietarilaissyntyistä ja venäjäntaitoista Bertel Gripenbergiä, joka majoitti Gorkin kartanoonsa ja toimi kirjailijan tulkkina tämän pakoillessa Venäjän viranomaisia Suomessa vuonna 1906 (SLSA 452).

${ }^{8}$ Разыгралась чтой-то вьюга, Ой, вьюга, ой, вьюга!

Не видать совсем Аруг Аруга

За четыре за шага! 
Снег воронкой завился,

Снег столбушкой поднялся...

- Ох, пурга какая, спасе!

- Петька! Эй, не завирайся!

(Blok 1918.)

${ }^{9}$ Käännösantologian vastaanotosta suomenruotsalaisessa lehdistössä, ks. Holmström 1990.

${ }^{10}$ Sama kritiikki on toistunut myöhemminkin, ks. esim. Wahlund 1948 ja Hellman 2014, 91.

${ }^{11}$ Severjanin (oik. Igor Lotarjov, 1887-1941) oli aikanaan poikkeuksellisen valovoimainen ilmiö, jonka runous puhutteli laajoja piirejä: Ivan Bunin toteaa muistelmissaan, että Severjaninin tunsivat "paitsi kaikki lukiolaiset, opiskelijapojat ja -tytöt sekä nuoret upseerit, myös monet kauppa-apulaiset, kätilöt, kauppamatkustajat ja kadetit" (Bunin 1967, 298). 1910-luvulla runoilija tunnettiin erityisesti "runokonserteistaan" (poezokontsert). Myöhemmin hän teki kiertueita myös ulkomaille; Helsingissä hän vieraili paikallisen venäläisen kauppiasyhdistyksen kutsumana lokakuussa 1923 (Leinonen 1991, 8) ja piti viikon aikana kolme runoiltamaa (Severjanin 1988, 50). Severjaninia kritisoitiin usein aiheiden banaaliudesta, mutta hänen runojensa rytmiikka ja neologismit saivat myönteistä huomiota jo aikalaiskritiikissä (ks. Terjohina \& Šubnikova-Guseva 2005, 295-297; Tsvetajeva 1987). Virossa asuessaan Severjanin kirjoitti pääasiassa luonto- ja rakkauslyriikkaa ja loi tiiviit suhteet virolaisiin modernisteihin. Severjaninin vaikutuksen voikin havaita esimerkiksi Henrik Visnapuun ja Albert Kivikasin tuotannossa (ks. Hennoste 2016, 321-323; Visnapuu 1921, 127-139).

${ }^{12}$ Hemmerin venäjän kielen ja kirjallisuuden alan pro gradu -tutkielma Helsingin yliopistossa käsitteli Nadsonia. Hän myös esitteli ja käänsi Nadsonia Finsk Tidskriftissä vuonna 1916 (ks. Hemmer 1916).

13 Ананасы в шампанском! Ананасы в шампанском!

УАивительно вкусно, искристо и остро!

Весь я в чем-то норвежском! Весь я в чем-то испанском!

ВАохновцяюсь порывно! И берусь за перо!

Стрекот аэропланов! Беги автомобилей!

Ветропросвист экспрессов! Крылолёт буеров!

Кто-то здесь зацелован! Там кого-то побили!

Ананасы в шампанском - это пульс вечеров!

В группе Аевушек нервных, в остром обществе Аамском Я трагедию жизни претворю в грезофарс...

Ананасы в шампанском! Ананасы в шампанском!

Из Москвы - в Нагасаки! Из Нью-Йорка - на Марс!

(Severjanin 1988.)

${ }^{14}$ Södergranin innostus Severjaniniin käy hyvin ilmi myös hänen Ultraan kirjoittamastaan runoilijaesittelystä. Esittelyä ei voi väittää analyyttiseksi, mutta silti Södergranin ylistyksessä nousee varsin tarkkanäköisesti esiin usein myöhemminkin Severjaninin kohdalla esitetty 
näkemys tämän runouden lapsenomaisuudesta, jonka hän näkee yhteydessä runoilijan ensisijaiseen yleisöön: "Han är en fjäril, ett barn, det finnes mycken omedveten visdom i honom. [--] Hans rätta publik är ungdomen, den sorglösa ungdom, som av intet ont vet, som vill älska och smeka och fånga en solstråle, som älskar livet och (den av fulingarna så förkättrade) skönheten.” (Södergran 1922, 72.)

${ }^{15}$ Nikolai Gumiljov (1886-1921), akmeismin johtohahmo ja Ahmatovan puoliso, joka menehtyi sisällissodassa valkoisten puolella. Gumiljovin kypsää tuotantoa leimaa kiinnostus filosofiseen problematiikkaan ja eksoottisiin seutuihin, erityisesti Afrikkaan.

\section{Kirjallisuus}

\section{Primäärilähteet}

Ahmatova, Anna 1932. Harmaasilmäinen kuningas. (Seroglasyi korol, 1912.) Suom. Katri Suoranta. Nuori Voima 1932, 186.

Blok, Aleksandr 1918. Dvenadtsat. Znamja truda.

Blok, Aleksandr 1921a. Die Zwölf. (Dvenadtsat, 1918.) Ü: Wolfgang E. Groeger. Berlin: Newa.

Blok, Aleksandr 1921b. Skythen. Die Zwölf. (Skify; Dvenadtsat, 1918.) Ü: Reinhold v. Walter. Berlin: Verlag Skythen.

Blok, Aleksandr 1924. De tolv. (Dvenadsat, 1918.) Övers. Rafael Lindqvist. Teoksessa Sånger i rött och svart. Helsingfors: Holger Schildt, 18-36.

Blok, Aleksandr 1929. Skyytit. (Skify, 1918.) Suom. Yrjö Jylhä. Teoksessa Nykyaikaa etsimässä: Esseitä ja pakinoita. Helsinki: Otava, 202-206.

Gumiljov, Nikolai 1929. Yksinäisyys. (Odinotšestvo, 1909.) Suom. Katri Suoranta. Tulenkantajat 3, 46.

Jesenin, Sergei 1928. Förvandling. (Preobraženije, 1917.) Övers. Ina Behrsen. Quosego. Tidskrift for ny generation 3, 149.

Jesenin, Sergei 1929. [nimetön käännös]. (Sorokoust, 1920.) Suom. Olavi Paavolainen. Teoksessa Nykyaikaa etsimässä. Helsinki: Otava, 220, 222-223.

Jesenin, Sergei 1935. Uusi Venäjä. (Rus Sovetskaja, 1924.) Suom. Ami Aarto. Tulenkantajat 49, 5.

Lyriska översättningar. 1922. Övers. Jarl Hemmer. Helsingfors: Holger Schildt, 1922.

Maailmankirjallisuuksien kultainen kirja. Slaavilaiset kirjallisundet. 1936. Suom. V. K. Trast. Porvoo - Helsinki: WSOY.

Majakovski, Vladimir 1929. 150 miljoonaa. (150 000 000, 1921.) Suom. Olavi Paavolainen. Teoksessa Nykyaikaa etsimässä. Helsinki: Otava, 213-217.

Modern Russian Poetry: An Anthology. Transl. Babette Deutsch \& Avrahm Yarmolinsky.

New York: Brace Harbourt.

Poezija bolševistskih dnei. 1921. Berlin: Mysl.

Runon pursi. 1934. Suom. Yrjö Jylhä. Porvoo - Helsinki: WSOY. 
Rysk litteratur. 1912. Övers. Alfred Jensen. Stockholm: Norstedts.

Rysslands judiska skalder. 1935. Övers. Rafael Lindqvist. Helsingfors: Blinkfyren.

Severjanin, Igor 1922a. Ouverture. (Uvertjura, 1915). Övers. Edith Södergran. Ultra.

Kirjallistaiteellinen aikakauslehti - Tidskrift för ny konst och litteratur 2, 20.

Severjanin, Igor 1922b. Insjöballad. (Ozerovaja ballada, 1910.) Övers. Edith Södergran. Ultra. Kirjallistaiteellinen aikakauslehti - Tidskrift för ny konst och litteratur 8, 108.

Severjanin, Igor 1930. Ouverture. (Uvertjura, 1915). Suom. Uuno Kailas. Tulenkantajat 3, 59.

Severjanin, Igor 1988. Uvertjura. Teoksessa Igor Severjanin: Stihotvorenija. Moskva: Sovetskaja Rossija, 259.

Sånger $i$ rött och svart. Ett urval ryska dikter frän bolsjevismens dagar. 1924. Övers. Rafael Lindqvist. Helsingfors: Holger Schildt.

Ur Rysslands sång I-II. 1904-1936. Övers. Rafael Lindqvist. Helsingfors: Blinkfyren.

\section{Sekundäärilähteet}

Baschmakoff, Natalia \& Marja Leinonen 2001. Russian Life in Finland 1917-1939: A Local and Oral History. Studia Slavica Finlandensia XVIII. Helsinki: Institute for Russian and East European Studies.

Blinkfyren 1928 ("Kungsnummer"). Juni 1928.

Bodin, Per-Arne 1987. Några kommentarer till Edith Södergrans ryska dikt. Historiska och litteraturhistoriska studier 62, 257-266.

Broemer, Marlene 2009. War and Revolution in St. Petersburg: Modernist Links in the Poetry of Edith Södergran and Anna Andreevna Akhmatova. PhD dissertation. Helsinki: University of Helsinki.

Bunin, Ivan 1967. Sobranie sotšineni v 9 tomah. Tom 9. Moskva: Hudožestvennaja literatura.

Dahl, Hjalmar 1924. Skyter och solbringare. Esipuhe teokseen Sånger i rött och svart. Ett urval ryska dikter från bolsjevismens dagar. Svensk tolkning av Rafael Lindqvist. Helsingfors: Holger Schildt, iii-viii.

Ehrenburg, Ilja 1927. Uusi romantiikka. (Romantizm naših dnei, 1925.) Suom. Olavi Paavolainen. Tulenkantajien albumi 4, 37-54.

Hekkanen, Raili 2010. Englanniksiko maailmanmaineeseen? Suomalaisen proosakaunokirjallisuuden kääntäminen englanniksi Isossa-Britanniassa vuosina 1945-2003. Helsinki: Helsingin yliopisto, Nykykielten laitos.

Hellman, Ben 2008. Puškinista Peleviniin. Venäläisen kaunokirjallisuuden suomennosten bibliografia 1876-2007. Helsinki: Helsingin yliopisto. 
Hellman, Ben 2009. Biblion. A Russian Publishing House in Finland. Teoksessa Vstretši i stolknovenija - Stati po russkoi literature. Meetings and Clashes - Articles on Russian Literature. Slavica Helsingiensia 36. Helsinki: University of Helsinki, 175-198.

Hellman, Ben 2014. Rafael Lindqvist (1867-1952). Ajan kohina 2, 89-91.

Hemmer, Jarl 1916. En essay och några öfversättningar. Finsk Tidskrift 81, 219-223.

Hennoste, Tiit 2016. Eesti kirjanduslik avangard 20. sajandi algul. Hüpped modernismi poole I. Tallinn \& Tartu: Tartu ülikooli kirjastus.

Holmström, Roger 1990. Bolsjevikfaran i öster. Reflexioner kring finlandssvensk modernism och den unga ryska dikten. Carina Amicorum. Carin Davidsson septuagenariae. Åbo: Åbo Akademis Förlag, 125-135.

Hübner, Friedrich 2012. Russische Literatur des 20. Jahrhunderts in deutschsprachigen Übersetzungen. Eine kommentierte Bibliographie. Köln et al.: Böhlau.

Håkanson, Nils 2012. Fönstret mot öster. Rysk skönlitteratur i svensk översättning 19792010 med en fallstudie av Nikolaj Gogols svenska mottagande. Stockholm: Ruin.

Jänis, Marja \& Pekka Pesonen 2007. Venäläinen kirjallisuus. H. K. Riikonen et al. (toim.), Suomennoskirjallisuuden historia. Osa 2. Helsinki: SKS, 189-205.

Leinonen, Marja 1991. Helsingin venäläinen kauppiasyhdistys r.y. 1918-1988. Historiikki. Helsinki: Yliopistopaino.

Leppihalme, Ritva 2007. Kääntäjän strategiat. H. K. Riikonen et al. (toim.), Suomennoskirjallisuuden historia. Osa 2. Helsinki: SKS, 365-373.

Lindqvist, Rafael 1936. Förord. Ur Rysslands sång II. Del 3. Helsingfors: Blinkfyren.

Nag, Martin 2006. Russisk modernisme og Edith Södergran. Firspann! Solum Forlag, 265-337.

Olsson, Hagar 1924. Rysk revolutionsdikt i svensk tolkning. Svenska pressen 16.12.1924.

Olsson, Hagar 1925. Ett revolutionsmysterium. Ny generation. Helsingfors: Schildts, $72-76$.

Olsson, Hagar 1990. Edith Södergranin kirjeet. (Ediths brev, 1955.) Suom. Pentti Saaritsa. Helsinki: Otava.

Paavolainen, Olavi 1927. Esipuhe Ilja Ehrenburgin esseeseen. Tulenkantajien albumi 4, 27-36.

Paavolainen, Olavi 1929. Venäläisiä vallankumousrunoilijoita. Block - Majakovski Jessenin. Nykyaikaa etsimässä. Helsinki: Otava, 196-225. (Julkaistu ensimmäisen kerran: Aitta 2/1928, 36-52.)

Pachmuss, Temira 1988. Russian Literature in the Baltic States between the World Wars. Columbus, Ohio: Slavica Publishers.

Pym, Anthony 1998. Method in Translation History. Manchester: St. Jerome Publishing.

[pilapiirros Bertel Gripenbergistä ja Rafael Lindqvististä] Quosego 1/1928, 26. 
Riikonen, H. K. 2014. Nukuin vasta aamuyöstä: Olavi Paavolainen 1903-1964. Helsinki: Gummerus.

Riikonen, H. K. 2016. Olavi Paavolaisen Neuvostoliittoa käsittelevät kirjoitukset. Ville Laamanen \& H. K. Riikonen (toim.), Olavi Paavolainen. Volga virtaa nyt Moskovaan. Kirjoituksia Neuvostoliitosta. Helsinki: Teos, 13-46.

Ruutu, Hanna 2011. Diktens uppror. Om Henry Parland och den ryska modernismen. Clas Zilliacus (red.), Erhållit Europa / vilket härmed erkännes. Henry Parland-studier. Helsingfors: SLS \& Atlantis, 145-156.

Severjanin, Igor 1988. Bengt Jangfeldt \& Rein Kruus (red.), Igor Severjanin: Pisma k Avguste Barabanovoi 1916-1938. Stockholm: Almqvist \& Wicksell International.

Stam, Per 1998. Krapula. Henry Parland och romanprojektet Sönder. Helsingfors: SLS.

Suomela-Härmä, Elina 2007. Ranskan kirjallisuus. H. K. Riikonen et al. (toim.), Suomennoskirjallisuuden historia. Osa 2. Helsinki: SKS, 104-118.

Södergran, Edith 1922. Igor Severjanin. Ultra. Kirjallistaiteellinen aikakauslehtiTidskrift för ny konst och litteratur 5, 72-73.

Terjohina, V. \& N. Šubnikova-Guseva 2005. Kritika o tvortšestve Igorja Severjanina. V. Terjohina, \& N. Šubnikova-Guseva (red.), Igor Severjanin. Tsarstvennyi pajats. Sankt-Peterburg: Rostok, 295-409.

Tsvetajeva, Marina 1987 (1931). Neotpravlennoje pismo Igorju Severjaninu. Venok poetu. Igor Severjanin. Tallinn: Eesti raamat, 22-24.

Visnapuu, Henrik 1921. Vanad ja vastsed poeedid. Tartu: Noor-Eesti kirjastus.

Wahlund, Per Erik 1948. Denaturerad sovjetvers. Nya Pressen 16.1.1948.

Witt-Brattström, Ebba 1997. Edith Södergran och modernismens födelse. Stockholm: Norstedts.

Ylioppilasmatrikkeli 1853-1899. Grönlund, Julius. http://www.helsinki.fi/ylioppilasmatrikkeli/1853-1899/henkilo.php?id=24930 (10.9.2016.)

Zilliacus, Clas 2014. Världsherraväldets lokalavisor: Ultra, Quosego och andra handlingar från modernismens 1920-tal. Ultra och Quosego. Faksimilutgåva. Helsingfors \& Stockholm: SLS \& Atlantis, ix-xxvii.

Åkerström, Hans 2010. Bibliografi över rysk skönlitteratur översatt till svenska. Göteborg: Institutionen för språk och litteraturer, Göteborgs universitet.

\section{Arkistolähteet}

SLSA 452. Bertel Gripenbergs diverse urklipp.

SLSA 566. Edith Södergrans arkiv.

SLSA 774. Helena Södergrans minnesanteckningar.

SLSA 842. Rafael Lindqvists handlingar. 